\title{
SUPPRESSION OF Urochloa brizantha AND U. ruziziensis BY GLYPHOSATE UNDERDOSES ${ }^{1}$
}

\author{
SUZETE FERNANDES LIMA ${ }^{2 *}$, LEANDRO SPÍNDOLA PEREIRA ${ }^{2}$, GUSTAVO DORNELES DE SOUSA $^{2}$, \\ GUSTAVO SILVA DE OLIVEIRA ${ }^{2}$, ADRIANO JAKELAITIS $^{2}$
}

\begin{abstract}
Intercropping of Urochloa species with corn is an alternative to enable the no-tillage system, besides influencing weed community. Therefore, the investigation of underdoses of the herbicide glyphosate to manage grasses in intercropping systems, avoid grain yield losses, and make feasible intercropping in agricultural areas is important. This study aimed to evaluate glyphosate underdoses in the suppression of Urochloa brizantha cv. Marandu and Urochloa ruziziensis and weed control. Two tests were conducted under field conditions in a randomized block design with four replications and eight treatments consisting of increasing glyphosate doses $\left(0,54,108,270,378,540,756\right.$, and $1.080 \mathrm{~g}$ a.e. ha $\left.^{-1}\right)$. All treatments received a dose of $1.200 \mathrm{~g}$ a.i. ha ${ }^{-1}$ of atrazine. Evaluations of phytointoxication of brachiaria plants were carried out at 7 , 14, 21, and 28 days after application. Moreover, total dry matter, leaf dry matter, stem dry matter, leaf to stem ratio, and canopy height of brachiaria plants and density and dry matter production of weed community were evaluated at 80 and 125 days after sowing. Glyphosate underdoses lower than 238 and $105 \mathrm{~g}$ a.e. ha ${ }^{-1}$ have potential to be investigated aiming at the management of $U$. brizantha cv. Marandu and $U$. ruziziensis, respectively.
\end{abstract}

Keywords: Weeds. No-tillage system. Intercropping. Integrated crop-livestock system.

\section{SUPRESSÃO DE Urochloa brizantha e U. ruziziensis POR SUBDOSES DE GLYPHOSATE}

RESUMO - O consórcio de espécies de Urochloa com milho é uma alternativa para viabilizar o Sistema Plantio Direto, além de influenciar na comunidade de plantas daninhas. Assim torna-se importante pesquisar subdoses do herbicida glyphosate para o manejo da gramínea no consórcio, para evitar perdas de produção de grãos e viabilizar o consórcio em áreas agrícolas. Objetivou-se avaliar subdoses de glyphosate na supressão de Urochloa brizantha cv. Marandu e Urochloa ruziziensis e o controle de plantas daninhas. Dois ensaios foram conduzidos em campo em delineamento experimental de blocos casualizados, com quatro repetições e oito tratamentos, formados por doses crescentes do herbicida glyphosate $(0 ; 54 ; 108 ; 270 ; 378 ; 540 ; 756 \mathrm{e} 1.080 \mathrm{~g}$ de e.a. ha $\left.^{-1}\right)$. Em todos os tratamentos foram adicionados $1.200 \mathrm{~g}$ de i.a. ha ${ }^{-1}$ de atrazine. Foram realizadas avaliações de fitointoxicação de plantas de braquiária aos 7, 14, 21 e 28 dias após a aplicação. E aos 80 e 125 dias após a semeadura foram realizadas avaliações de produção de massa seca total, massa seca de folha, massa seca de colmos, relação folha:colmo e altura do dossel, além da densidade e produção de massa seca da comunidade de plantas daninhas. Subdoses de glyphosate abaixo de 238 e de $105 \mathrm{~g}$ de e.a. ha ${ }^{-1}$ possui potencial para serem pesquisadas visando o manejo de U. brizantha cv. Marandu e U. ruziziensis, respectivamente.

Palavras-chave: Plantas daninhas. Sistema Plantio Direto. Cultivos consorciados. Integração lavoura pecuária.

\footnotetext{
${ }^{*}$ Corresponding author

${ }^{1}$ Received for publication in 10/14/2017; accepted in 04/01/2019.

Paper extracted from the doctoral thesis of the first author.

${ }^{2}$ Department of Phytotechnology, Instituto Federal de Educação, Ciência e Tecnologia Goiano, Rio Verde, GO, Brazil; suzete.lima@yahoo.com.br - ORCID: 0000-0001-6077-3070, leandrop629@gmail.com - ORCID: 0000-0003-0016-0330, gustavodorneles7888@gmail.com - ORCID: 0000-0003-2542-7409, gustavosilvadeoliveira147@gmail.com - ORCID: 0000-0002-98969156, ajakelaitis@yahoo.com.br-ORCID: 0000-0003-0093-9846.
} 


\section{INTRODUCTION}

The adoption of crop management techniques is an important strategy for integrated weed management in order to reduce the occurrence and selection of agricultural areas (LIMA et al., 2014). Thus, it is essential to use complementary management practices to reduce the occurrence of difficult-to-control weeds, which are responsible for increasing production costs (GOMES JÚNIOR; CHRISTOFFOLETI, 2008). The integrated cultivation of annual crops with forages has been a viable alternative (GARCIA et al., 2012) aiming at better soil cover and straw formation (CHIODEROLI et al., 2010), as well as reducing weed occurrence (LIMA et al., 2014).

In the Cerrado, intercropping between corn and forage crops is a technology that allows maintaining corn grain production and increasing straw production in order to enable no-tillage with soybean-corn succession (QUEIROZ et al., 2016; ALMEIDA et al., 2017). The use of no-tillage system (NTS) in areas with a deficiency of straw or soil cover leads to an increase in the infestation of herbicide-tolerant or resistant weeds and hence to a reduction of up to $50 \%$ in soybean yield when compared to sowing carried out on straw of Urochloa spp., which presents high yield and long persistence (LAMAS, 2008).

The intercropping of corn with forages is a common practice because it allows better land use and sustainability of the agricultural system, as well as the early supply of high-yield forage for grazing and straw formation for soybean sowing in the subsequent season (PARIZ et al., 2011). However, intercropping systems present competition among crop species, in addition to that naturally establish by the weed community. This competition, if not properly managed, can economically make this cropping system economically unfeasible (ADEGAS; VOLL; GAZZIERO, 2011; ALVES et al., 2013). According to Adegas, Voll and Gazziero (2011), corn grain yield can be reduced by up to $45 \%$ due to the competition if forage management is not carried out.

Competition can be mitigated with the adoption of agronomic practices, such as herbicide application, which can partially inhibit the initial growth rate of forages (ADEGAS; VOLL; GAZZIERO, 2011; REZENDE et al., 2014). Therefore, to achieve success in the intercropping between annual and forage crops it is necessary to guarantee the initial competitive advantage of the crop by environmental resources, which can be achieved with applications of herbicide underdoses.

With the technology of genetically modified RR crops, the herbicide glyphosate became selective for these crops. This herbicide is used for vegetation management before crop sowing, especially in NTS areas, as well as in post-emergence applications in genetically modified crops resistant to this molecule (GOMES JÚNIOR; CHRISTOFFOLETI, 2008; GALLI, 2009; ALBRECHT et al., 2014).

In this context, glyphosate has the potential to be used in the management of forages intercropped with RR-corn since it promotes essential effects on the growth and development of plants when applied in underdoses. However, there is still little information on the behavior of forages to the application of glyphosate underdoses. Therefore, this study aimed to evaluate glyphosate underdoses in the suppression of Urochloa brizantha cv. Marandu and Urochloa ruziziensis, in addition to its influence on weed control aiming at intercropping.

\section{MATERIAL AND METHODS}

This research was conducted in the southwest of Goiás. The soil of the experimental area is classified as a dystroferric Red Latosol and soil analysis at a depth of $0-20 \mathrm{~cm}$ showed a $\mathrm{pH}$ of 6.2 (SMP); $\mathrm{Ca}$ of $4.64, \mathrm{Mg}$ of $2.50, \mathrm{Al}^{3+}$ of $0.04, \mathrm{H}+\mathrm{Al}$ of 4.5, CEC of 12.1, and $\mathrm{K}$ of $0.46 \mathrm{cmol}_{\mathrm{c}} \mathrm{dm}^{-3}$; P (Mehlich) of 13.1, $\mathrm{Cu}$ of 2.3, Fe of 13, Mn of 59.3, $\mathrm{OM}$ of 3.62 , and $\mathrm{Zn}$ of $4.5 \mathrm{mg} \mathrm{dm}^{-3}$; base saturation of 62.8 , aluminum saturation of 0.5 , clay of 64.5 , silt 10.0 , and sand of $25.5 \%$.

According to Köppen classification, the regional climate is Aw type, i.e., a mesothermal, tropical savannah climate, with a rainy summer and a dry winter. The climatological data of the experimental period are shown in Figure 1. 


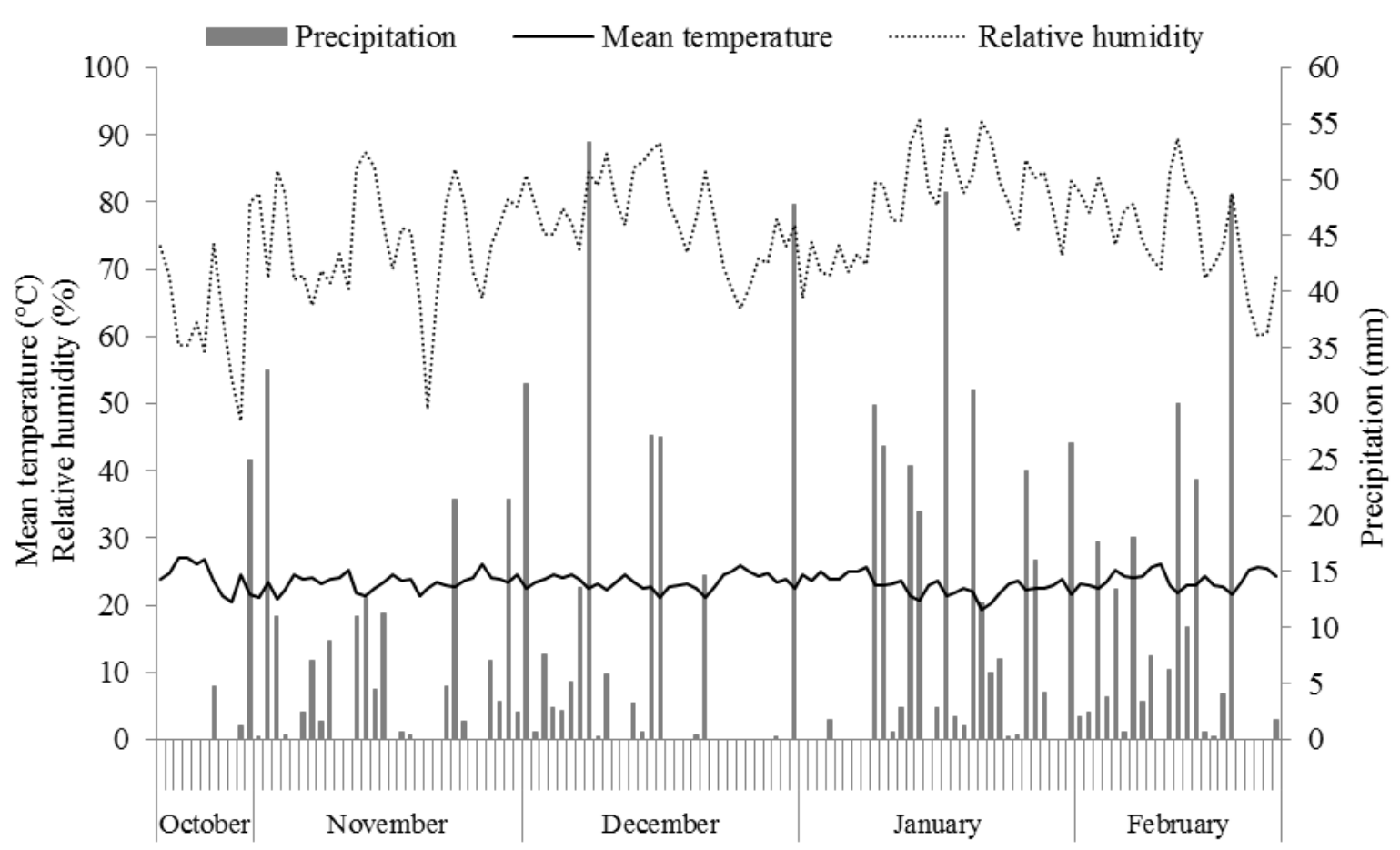

Figure 1. Mean air temperature, relative air humidity, and total daily precipitations during the experimental period (INMET, 2016/2017).

Two field experiments were carried out with a different forage species, U. brizantha cv. Marandu and $U$. ruziziensis. Before the experiment set up, natural vegetation composed of different weed species was chemically desiccated with glyphosate at a dose of $1.440 \mathrm{~g} \mathrm{ha}^{-1}$. Fifteen days later, soil tillage was carried using one plowing and two harrowing practices. Sowing was carried out on October 21, 2016, using $5 \mathrm{~kg} \mathrm{ha}^{-1}$ of viable pure seeds sown in rows spaced $0.50 \mathrm{~m}$ and $0.05 \mathrm{~m}$ deep. Sowing fertilization consisted of $150 \mathrm{~kg} \mathrm{ha}^{-1}$ of the NPK formulation $04-28-16$.

The experimental design was a randomized block design with four replications and eight treatments consisting of increasing glyphosate doses $\left(0,54,108,270,378,540,756\right.$, and $1.080 \mathrm{~g}$ a.e. $\left.\mathrm{ha}^{-1}\right)$ of the commercial formulation Transorb $480 \mathrm{~g} \mathrm{~L}^{-1}$. All treatments received $1.200 \mathrm{~g}$ a.i. $\mathrm{ha}^{-1}$ of atrazine (Atrazine $500 \mathrm{SC}^{\circledR}$ Nortox). Experimental plots consisted of 5 rows of $3 \mathrm{~m}$ in length, with a distance of $1 \mathrm{~m}$ between blocks. The useful area consisted of the two central rows without $0.5 \mathrm{~m}$ of borders on both sides.

Treatments were applied at 30 days after sowing (DAS) (November 20, 2016) with a $\mathrm{CO}_{2}$ pressurized research sprayer equipped with a boom with four TT11002 tips spaced $0.50 \mathrm{~m}$ placed at 0.5 $\mathrm{m}$ height in relation to plant surface and adjusted to a spray solution volume of $150 \mathrm{~L} \mathrm{ha}^{-1}$ and working pressure of $200 \mathrm{KPa}$. The application was performed in the morning from 7:00 to 9:30 a.m., under an air temperature of $27{ }^{\circ} \mathrm{C}$, relative air humidity of $76 \%$, wind speed of $1.0 \mathrm{~m} \mathrm{~s}^{-1}$, and moist soil at the surface.
Adjacent plots were protected at application time with plastic canvas to avoid drift.

The percentage of plant phytointoxication was evaluated at 7, 14, 21, and 28 days after herbicide application (DAA), with a percentage scale of 0 to $100 \%$ was established, where 0 represented no injuries in plants and 100 represented plant death (VELINI; OSIPE; GAZZIERO, 1995).

Forage dry matter production was evaluated at 80 and 125 DAS (January 9 and February 23, 2017, respectively). Plants of Urochloa spp. were collected from $1.5 \mathrm{~m}$ of the central row of each experimental unit at $0.15 \mathrm{~m}$ height using a cleaver. After cutting, forage fresh matter was weighed and an aliquot of approximately $0.5 \mathrm{~kg}$ was taken to determine the dry matter. Leaves, stems, and senescent material were separated from this sample. They were then packed in paper bags and dried in a forced air circulation oven at $65{ }^{\circ} \mathrm{C}$ for 72 hours for dry matter determination.

The leaf to stem ratio (LSR) was calculated for both evaluation periods (at 80 and 125 DAS) by dividing the dry matter of leaves by stems. Forage canopy height was determined before each cut with a ruler graduated in $\mathrm{cm}$. The height was measured at two random points at each experimental unit.

After the first evaluation, carried out at 80 DAS, a standardization cut was performed in the entire experimental area with a cleaver. The interval between the first and second forage cutting was 45 days in both experiments.

Weeds were evaluated at 80 and 125 DAS. For this, two sample squares of $0.25 \mathrm{~m}^{2}$ were 
randomly placed per experimental unit, and the species were identified, separated, and counted. Subsequently, weeds were cut close to the soil, and the shoot was packed in paper bags for dry matter determination in a forced air circulation oven at $65^{\circ}$ $\mathrm{C}$ for 72 hours and weighing on an analytical balance.

The data were submitted to analysis of variance by the $F$ test $(p<0.05)$ using the statistical software SAEG - Sistemas para Análises Estatísticas, version 9.0 (RIBEIRO JÚNIOR, 2001). Subsequently, in case of statistical significance, a regression analysis was performed using the software Sigmaplot (SISTAT SOFTWARE, version 12.0, San Jose). The data were adjusted to a non-linear threeparameter sigmoidal regression equation, as follows:

$$
y=a /\left(1+\exp \left(-\frac{x-x 0}{b}\right)\right)
$$

where $\mathrm{y}$ is the response variable, $\mathrm{x}$ is the

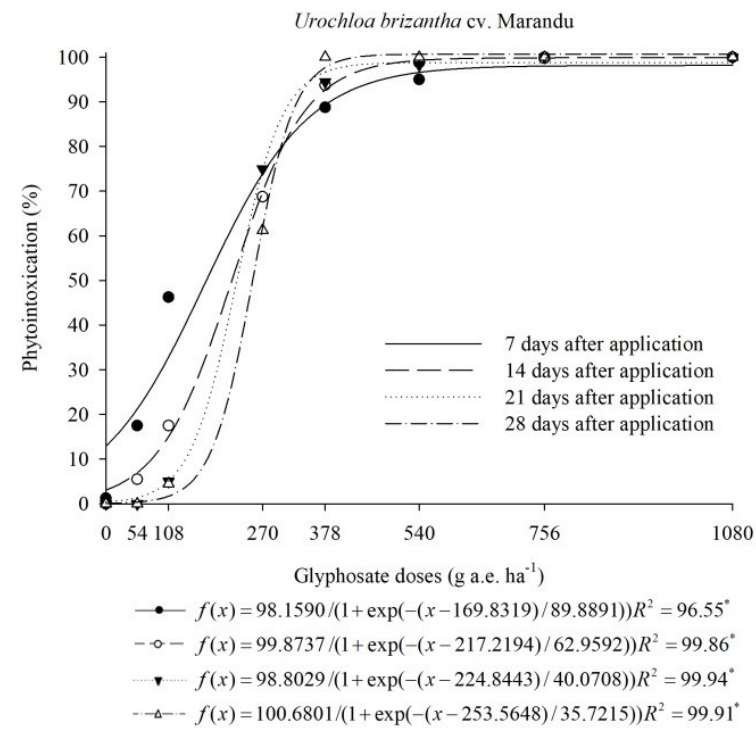

herbicide dose, and $a, x 0$, and $b$ are the equation parameters, where $a$ is the difference between the maximum and minimum points of the curve, $x 0$ is the dose that provides $50 \%$ response of the variable, and $b$ the slope of the curve.

\section{RESULTS AND DISCUSSION}

Regression curves adjusted by the sigmoidal model and the coefficients of determination for the means obtained for the percentage of phytointoxication of forage species as a function of glyphosate underdoses are shown in Figure 2. The data presented a good fit, with $\mathrm{R}^{2}$ between 96.55 and $99.99 \%$. Both forage species presented a similar behavior, with a lower percentage of injuries at lower underdoses and the total plant control at higher underdoses.

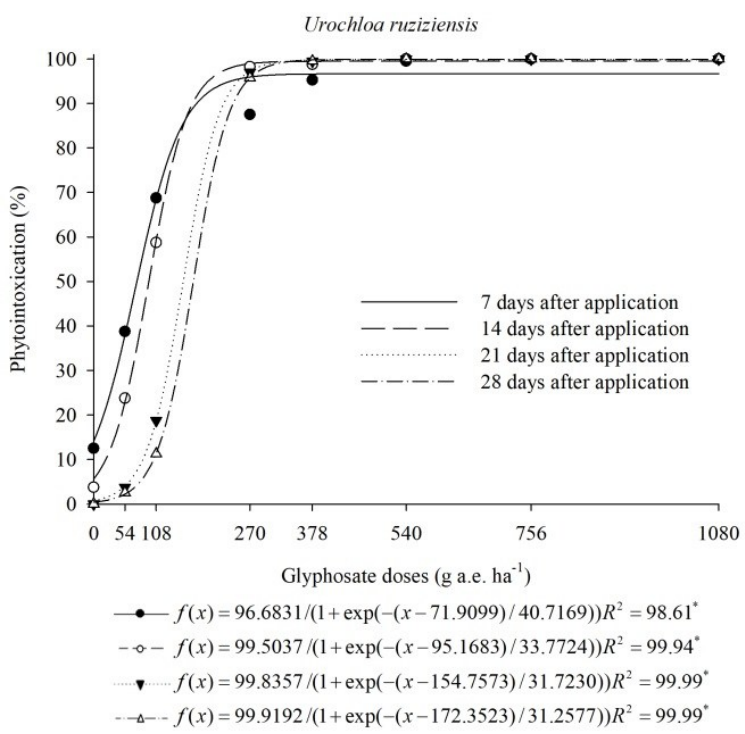

Figure 2. Regression curves for the means of the percentage of phytointoxication of Urochloa brizantha cv. Marandu and Urochloa ruziziensis at 7, 14, 21, and 28 days after application (DAA) as a function of glyphosate doses $(0,54,108,270$, $378,540,756$, and $1.080 \mathrm{~g}$ a.e. ha $\left.{ }^{-1}\right)$ combined with atrazine $\left(1.200 \mathrm{~g} \mathrm{a.i.} \mathrm{ha}{ }^{-1}\right)$.

The highest plant phytointoxication was observed up to 14 DAA at underdoses lower than $160 \mathrm{~g}$ a.e. $\mathrm{ha}^{-1}$ for $U$. ruziziensis and $210 \mathrm{~g}$ a.e. $\mathrm{ha}^{-1}$ for $U$. brizantha. After this period, injury symptoms began to decrease, demonstrating only a grassgrowth stoppage with a subsequent vegetative growth with the emission of new leaves. According to Nascentes (2016), symptoms due to glyphosate can be observed about seven days after its application. The first symptom is the appearance of chlorotic leaves, which evolve to tissue necrosis since glyphosate acts on the biosynthesis of amino acids and phenolic compounds.

The parameter $a$ of the equation was high for both species in the four evaluation periods, i.e., from 7 to 28 DAA a high difference was observed between the maximum and minimum percentage of phytointoxication due to the application of glyphosate underdoses, showing low injury symptoms at lower underdoses and marked injury symptoms at higher underdoses. At underdoses higher than 480 and 240 g a.e. ha ${ }^{-1}$ for $U$. brizantha and $U$. ruziziensis, respectively, plants presented phytointoxication above $95 \%$ from 7 DAA.

The parameter $b$ of the equation presented a higher value for both species at 7 DAA, but its values were gradually decreasing from 14 DAA, reaching the lowest value at $28 \mathrm{DAA}$. It shows that at the beginning of the evaluation, the slope of the curve was lower, i.e., plants had injury symptoms at lower underdoses. At $28 \mathrm{DAA}$, the slope of the curve tends to be more pronounced because plants recover from phytointoxication at the lowest underdoses at 7 DAA and are controlled at the highest underdoses. 
The parameter $x 0$ of the equations followed the same behavior for both kinds of grass. At 7 DAA, a lower underdose presented 50\% of phytointoxication in plants, i.e., $169 \mathrm{~g}$ a.e. $\mathrm{ha}^{-1}$ for $U$. brizantha cv. Marandu and $71 \mathrm{~g}$ a.e. $\mathrm{ha}^{-1}$ for $U$. ruziziensis. A higher underdose was required at 28 DAA to occur the same degree of injury, i.e., $253 \mathrm{~g}$ a.e. ha ${ }^{-1}$ for $U$. brizantha and $172 \mathrm{~g}$ a.e. $\mathrm{ha}^{-1}$ for $U$. ruziziensis, evidencing plant recovery after being submitted to low glyphosate underdoses. Also, $U$. ruziziensis is more susceptible than $U$. brizantha cv. Marandu to the effects of glyphosate, requiring a lower underdose to occur $50 \%$ of injuries in plants.

Glyphosate underdoses higher than 270 g a.e. $\mathrm{ha}^{-1}$ controlled all plants of $U$. ruziziensis at 28 DAA. On the other hand, a glyphosate underdose equal to or higher than $355 \mathrm{~g}$ a.e. $\mathrm{ha}^{-1}$ was required to control plants of $U$. brizantha cv. Marandu. Thus,

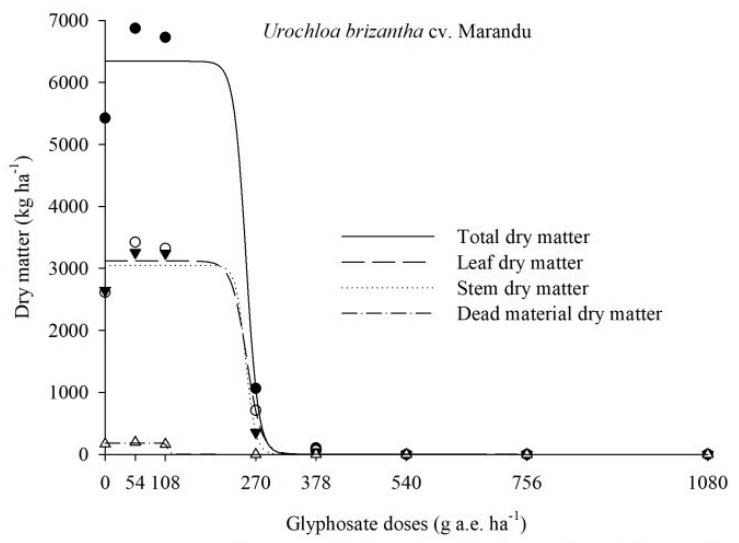

- $f(x)=6340.9480 /(1+\exp (-(x-252.4659) /-10.9472)) R^{2}=98.22^{*}$

$\leadsto-f(x)=3119.0657 /(1+\exp (-(x-253.5986) /-13.4209)) R^{2}=97.71^{*}$

- $f(x)=3047.6705 /(1+\exp (-(x-252.0703) /-8.8337)) R^{2}=98.55^{*}$

$\triangle-f(x)=181.1421 /(1+\exp (-(x-113.6766) /-2.7758)) R^{2}=99.31^{\circ}$

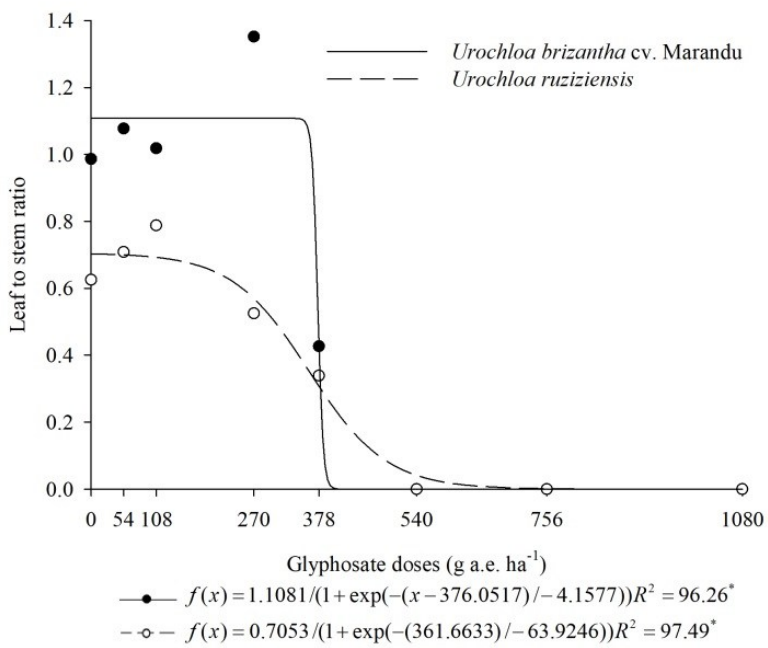

it shows that species of the genus Urochloa have different susceptibility to the same herbicide, with a different behavior when submitted to the same underdose. In this sense, Silva et al. (2013) observed a higher sensitivity to desiccation of $U$. ruziziensis when compared to $U$. decumbens and $U$. brizantha cv. Piatã using glyphosate. Ceccon and Concenço (2014) also verified that $U$. ruziziensis is easily controlled in desiccation management.

Figure 3 shows the total dry matter, leaf dry matter, stem dry matter, dead material dry matter, leaf to stem ratio, and forage height at $80 \mathrm{DAS}$ at the first cut of forages. Glyphosate underdoses higher than 238 and $105 \mathrm{~g}$ a.e. $\mathrm{ha}^{-1}$ promoted a reduction in biomass production of more than $20 \%$ for $U$. brizantha cv. Marandu and U. ruziziensis, respectively.
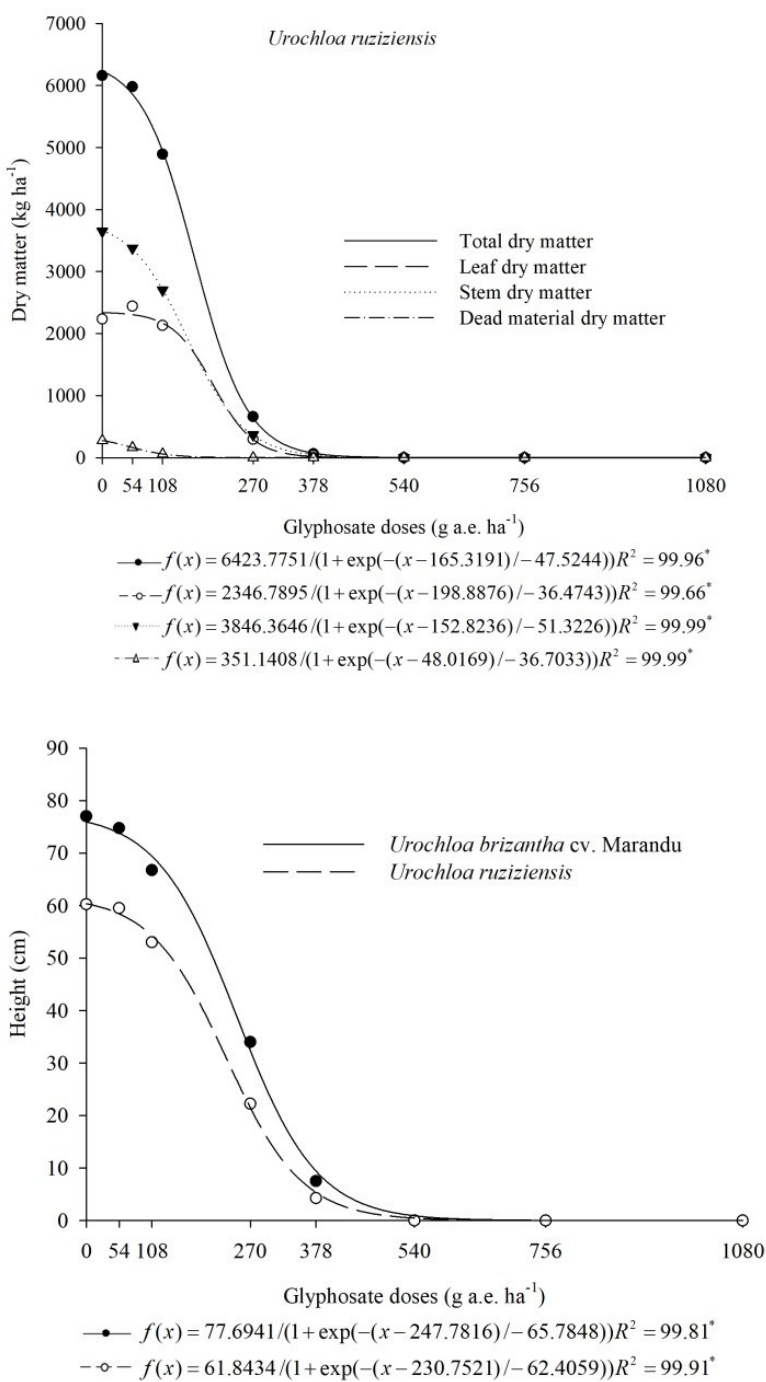

Figure 3. Regression curves for the means of the total dry matter $\left(\mathrm{kg} \mathrm{ha}^{-1}\right)$, leaf dry matter $\left(\mathrm{kg} \mathrm{ha}^{-1}\right)$, stem dry matter $\left(\mathrm{kg} \mathrm{ha}^{-1}\right)$, dead material dry matter $\left(\mathrm{kg} \mathrm{ha}^{-1}\right)$, leaf to stem ratio, and canopy height $(\mathrm{cm})$ for Urochloa brizantha $\mathrm{cv}$. Marandu and Urochloa ruziziensis at 80 days after sowing (DAS) as a function of glyphosate doses $(0,54,108,270,378,540,756$, and $1.080 \mathrm{~g}$ a.e. $\left.\mathrm{ha}^{-1}\right)$ combined with atrazine $\left(1.200 \mathrm{~g}\right.$ a.i. $\left.\mathrm{ha}^{-1}\right)$. 
Glyphosate underdoses higher than 320 and $430 \mathrm{~g}$ a.e. $\mathrm{ha}^{-1}$ were sufficient to completely cease the development of $U$. brizantha and $U$. ruziziensis plants, respectively, leading them to death. Thus, underdoses lower than those should be investigated for the management of these species.

No significant reduction in the production of total dry matter, leaf dry matter, and stem dry matter was observed for $U$. brizantha cv. Marandu up to an underdose of $220 \mathrm{~g}$ a.e. $\mathrm{ha}^{-1}$ and $U$. ruziziensis up to $50 \mathrm{~g}$ a.e. $\mathrm{ha}^{-1}$. Some species may present the hormesis effect, which is the stimulus to production when plants are submitted to the underdose of a product considered toxic at high doses (BELZ; DUKE, 2014; CEDERGREEN, 2008). Moraes (2016) studied in a greenhouse the hormesis effect on $U$. decumbens and observed that this species had maximum values of fresh and dry matter when submitted to a glyphosate underdose of $11.25 \mathrm{~g}$ a.e. $\mathrm{ha}^{-1}$. According to Duke et al. (2006), glyphosate underdoses inhibit lignin synthesis, which makes cell walls more elastic for a longer period, allowing a higher growth. Glyphosate underdoses higher than 220 and $50 \mathrm{~g}$ a.e. ha ${ }^{-1}$ for $U$. brizantha and $U$. ruziziensis, respectively, evidenced its herbicidal effect, with growth stoppage and consequent decline in forage production.

Both Urochloa species showed a tendency to increase the leaf to stem ratio when plants were submitted to higher glyphosate underdoses. Higher plant growth was observed at lower underdoses, which may result in competition for light and, consequently, stem elongation for leaf projection. According to Echeverria et al. (2016), stem elongation is stimulated by the competition between plants by light, in which leaves are projected higher and higher, leading to a lower leaf accumulation and hence a decrease in the leaf to stem ratio. LSR is an indication of the nutritional value index of forages, facilitating grazing and conferring better tolerance to the cut (RODRIGUES et al., 2008). According to Sbrissia and Silva (2001), LSR has varied relevance according to the forage species, being lower in species with a tender stem and lower lignification.

Canopy height followed the same behavior for both species, with lower heights due to an increase of glyphosate underdoses. It should be related to lower stem elongation and forage growth retardation that occurred as a function of the glyphosate action.

The data on total dry matter, the leaf to stem ratio, leaf dry matter, stem dry matter, and forage height at the second cut, performed at 125 DAS, are shown in Figure 4. Dead material dry matter was not significant, with means of 1.77 and $11.34 \mathrm{~kg} \mathrm{ha}^{-1}$ for $U$. brizantha and $U$. ruziziensis, respectively. At the second cut, with a 45-day interval, lower biomass production was observed for both forages when compared to the first cut, with the highest reduction when grasses were submitted to the highest glyphosate underdoses.

A reduction in biomass production, leaf dry matter, stem dry matter, and canopy height was observed in $U$. brizantha $\mathrm{cv}$. Marandu due to an increase of glyphosate underdoses. The absence of glyphosate led to a higher potential for resprouting. In this sense, $U$. ruziziensis showed a high potential for resprouting even when subjected to the application of glyphosate underdoses probably due to the recovery of toxic effects on forage by the herbicide. It may be related to its higher tillering capacity, allowing a higher area occupation and consequent soil cover.

The application of glyphosate underdoses subjected plants to stress, leading to a reduction in leaf area at the highest underdoses, which reduces the photosynthetic efficiency of remaining leaves, besides influencing the reserve level of these grasses and hence influencing the potential of development and resprout of the forage. Thus, the lower biomass production at the second cut may be related to the need to use reserve compounds to restore the photosynthetically active area since the number of green leaves determines the greater or lesser relevance of reserves in the shoot recovery, and only after a full recovery, plants are able to store reserve compounds again. According to Bortoluzzi et al. (2017), after grass defoliation, the forage portion that has residual leaf area and basal lateral buds is responsible for resprouting potential. During resprout, roots and stem base redirect the organic reserves (carbohydrates and proteins) to accelerate the reestablishment and vegetative growth of the forage (RODRIGUES et al., 2007). 

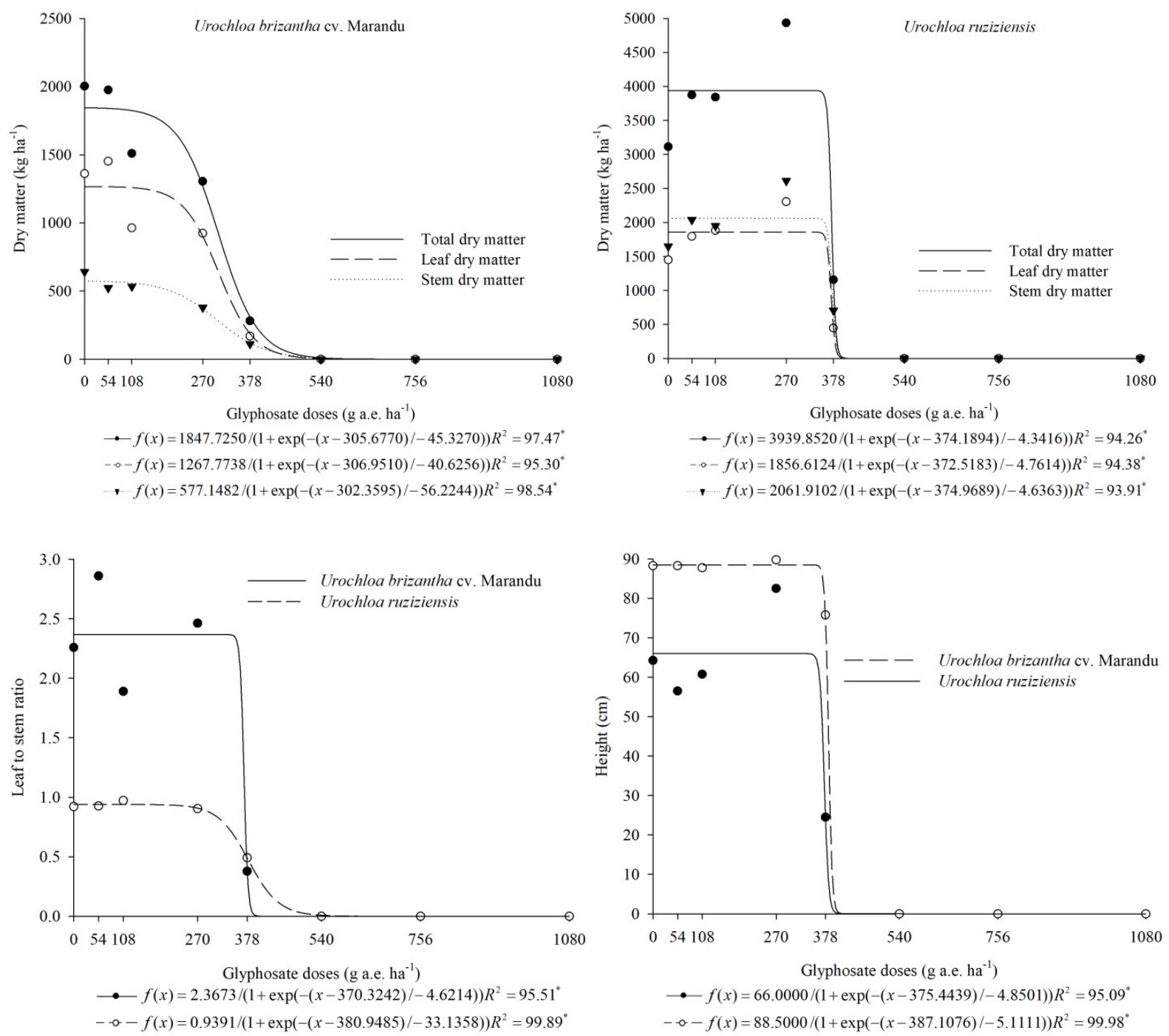

Figure 4. Regression curves for the means of the total dry matter $\left(\mathrm{kg} \mathrm{ha}^{-1}\right)$, leaf dry matter $\left(\mathrm{kg} \mathrm{ha}^{-1}\right)$, stem dry matter $\left(\mathrm{kg} \mathrm{ha}^{-1}\right)$, leaf to stem ratio, and canopy height $(\mathrm{cm})$ for Urochloa brizantha $\mathrm{cv}$. Marandu and Urochloa ruziziensis at 125 days after sowing (DAS) as a function of glyphosate doses $\left(0,54,108,270,378,540,756\right.$, and $1.080 \mathrm{~g}^{\text {a.e. }}$ ha $\left.^{-1}\right)$ combined $^{-1}$ with atrazine $\left(1.200 \mathrm{~g}\right.$ a.i. $\left.\mathrm{ha}^{-1}\right)$.

Table 1 shows the data of density and dry matter of weeds at 80 and 125 DAS. The main weeds in the experimental area were Commelina benghalensis, Cenchrus echinatus, Digitaria horizontalis, Eleusine indica, Cyperus rotundus, Alternanthera tenella, Nicandra physaloides, Ipomoea grandifolia, Ricinus communis, and Vigna angularis. Only $U$. ruziziensis showed a statistical difference in weed density at 80 DAS, with a higher infestation at highest glyphosate underdoses, which may be related to the lower development or control of the grass at these underdoses.

The absence of statistical difference at 80 DAS is related to the application of the herbicide atrazine, which controls the germination of weed seeds in the soil seed bank, besides exerting influence on the development of some eudicot weeds when the application is carried out at the beginning of their development.
A higher density and biomass production of weeds were observed at higher glyphosate underdoses at 125 DAS since a drastic reduction in the development or even death of grasses was observed at these underdoses, leaving the soil uncovered and favoring the germination and development of weeds. Also, the residual power of atrazine has already decreased in this period, not influencing weed community, whose half-life time, a parameter used to estimate the persistence of the product in the soil, is 55 days (RODRIGUES; ALMEIDA, 2011). However, the residual effect is highly influenced by edaphoclimatic conditions (ULBRICH; SOUZA; SHANER, 2005). High precipitation, above $240 \mathrm{~mm}$ monthly, occurred in December 2016 and January 2017 (Figure 1), the experimental period, may have contributed to a reduction in the residual effect of the herbicide atrazine. 
Table 1. Parameters of the regression equations obtained by the adjustment of sigmoidal model and determination coefficient $\left(\mathrm{R}^{2}\right)$ applied to the means of weed density (plants $\left.\mathrm{m}^{-2}\right)$ and weed dry matter $\left(\mathrm{g} \mathrm{m}^{-2}\right)$ in the cultivation of Urochloa brizantha cv. Marandu and Urochloa ruziziensis at 80 and 125 days after sowing (DAS) as a function of glyphosate underdoses $\left(0,54,108,270,378,540,756\right.$, and $1.080 \mathrm{~g}$ a.e. $\left.\mathrm{ha}^{-1}\right)$ combined with atrazine $\left(1.200 \mathrm{~g}\right.$ a.i. ha $\left.{ }^{-1}\right)$.

\begin{tabular}{|c|c|c|c|c|c|}
\hline & \multirow{2}{*}{ Variable } & \multicolumn{3}{|c|}{ Parameter $^{1}$} & \multirow{2}{*}{$\mathrm{R}^{2}$} \\
\hline & & $a$ & $b$ & $X 0$ & \\
\hline \multicolumn{6}{|c|}{ Urochloa brizantha cv. Marandu } \\
\hline $80 \mathrm{DAS}^{2}$ & $\mathrm{D}^{3}$ & \multirow{2}{*}{\multicolumn{3}{|c|}{ 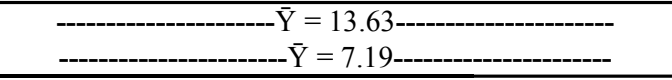 }} & $n s^{5}$ \\
\hline 80 DAS & $\mathrm{DM}^{4}$ & & & & $n s$ \\
\hline \multirow{2}{*}{125 DAS } & $\mathrm{D}$ & 32.6962 & 405.2994 & 625.3555 & $72.43^{*}$ \\
\hline & $\mathrm{DM}$ & 475.7536 & 28.9133 & 278.4676 & $85.38^{*}$ \\
\hline \multicolumn{6}{|c|}{ Urochloa ruziziensis } \\
\hline \multirow{2}{*}{80 DAS } & $\mathrm{D}$ & 16.4926 & 48.8633 & 203.6723 & $84.52^{*}$ \\
\hline & $\mathrm{DM}$ & ------ & $-\bar{Y}=1.67-$ & ------- & $n s$ \\
\hline \multirow{2}{*}{$125 \mathrm{DAS}$} & $\mathrm{D}$ & 21.0806 & 105.2132 & 357.1824 & $94.09^{*}$ \\
\hline & $\mathrm{DM}$ & 421.9460 & 104.6445 & 449.7000 & $99.26^{*}$ \\
\hline
\end{tabular}

${ }^{1}$ Model: $\mathrm{Y}=a /\left(1+\exp \left(-(\mathrm{x}-x 0) / b .{ }^{2} \mathrm{Days}\right.\right.$ after sowing. ${ }^{3} \mathrm{Wed}$ density. ${ }^{4} \mathrm{Weed}$ dry matter. ${ }^{5}$ Not significant. ${ }^{*}$ Significant by the $\mathrm{F}$ test $(\mathrm{p} \leq 0.05)$.

Grasses expressed their suppression potential on weed community at lower glyphosate underdoses. Grass growth, with consequent soil cover, inhibited weed growth. According to Lima, Timossi and Almeida (2016), the higher occupation of the soil surface by brachiaria reduces the density and development of weeds, showing the importance of using management practices for integrated weed management.

\section{CONCLUSIONS}

Forages had their growth strongly inhibited at glyphosate underdoses higher than $250 \mathrm{~g}$ a.e. $\mathrm{ha}^{-1}$ for $U$. brizantha cv. Marandu and $165 \mathrm{~g}$ a.e. ha ${ }^{-1}$ for $U$. ruziziensis. Glyphosate underdoses lower than 238 and $105 \mathrm{~g}$ a.e. $\mathrm{ha}^{-1}$ have potential to be investigated aiming at the management of $U$. brizantha $\mathrm{cv}$. Marandu and $U$. ruziziensis in intercropping. The grasses $U$. brizantha cv. Marandu and U. ruziziensis are efficient in suppressing weeds.

\section{REFERENCES}

ADEGAS, F. S.; VOLL, E; GAZZIERO, D. L. P. Manejo de plantas daninhas em milho safrinha em cultivo solteiro ou consorciado à braquiária ruziziensis. Pesquisa Agropecuária Brasileira, v. 46, n. 10, p. 1226-1233, 2011.

ALBRECHT, A. J. P. et al. O milho RR2 e o glyphosate: Uma Revisão. Revista Brasileira de Herbicidas, v. 13, n. 1, p. 58-67, 2014.

ALMEIDA, R. E. M. et al. Corn yield, forage production and quality affected by methods of intercropping corn and Panicum maximum. Pesquisa Agropecuária Brasileira, v. 52, n. 3, p. 170-176, 2017.

ALVES, V. B. et al. Milho safrinha consorciado com
Urochloa ruziziensis e produtividade da soja em sucessão. Revista Brasileira de Milho e Sorgo, v. 12, n. 3, p. 280-292, 2013.

BELZ, R. G.; DUKE, S. O. Herbicides and plant hormesis. Pest Management Science, v. 70, n. 5, p. 698-707, 2014.

BORTOLUZZI, F. M. et al. Fosfato natural reativo aplicado em épocas distintas e associado a fertilizantes nitrogenados afetam a produção de capim-marandu. Boletim de Indústria Animal, v. 74, n. 1, p. 9-16, 2017.

CECCON, G.; CONCENÇO, G. Produtividade de massa e dessecação de forrageiras perenes para integração lavoura-pecuária. Planta Daninha, v. 32, n. 2, p. 319-326, 2014.

CEDERGREEN, $\mathrm{N}$. Is the growth stimulation by low doses of glyphosate sustained over time? Environmental Pollution, v. 156, n. 3, p. 10991104, 2008.

CHIODEROLI, C. A. et al. Consorciação de braquiárias com milho outonal em plantio direto sob pivô central. Engenharia Agrícola, v. 30, n. 6, p. 1101-1109, 2010.

DUKE, S. O. et al. Hormesis: Is it an importante fator in herbicide use and allelopathy? Outlooks on Pest Management, v. 17, n. 1, p. 29-33, 2006.

ECHEVERRIA, J. R. et al. Acúmulo de forragem e valor nutritivo do híbrido de Urochloa 'BRS RB331 Ipyporã' sob pastejo intermitente. Pesquisa Agropecuária Brasileira, v. 51, n. 7, p. 880-889, 2016.

GALLI, A. J. B. A molécula glyphosate e a agricultura brasileira. In: VELINI, E. D.; MESCHEDE, D.; CARBONARI, C. A.; 
TRINDADE, M. L. B (Eds.). Glyphosate. Botucatu: FEPAF, 2009. v. 1, cap. 2, p. 17-19.

GARCIA, C. M. P. et al. Análise econômica da produtividade de grãos de milho consorciado com forrageiras dos gêneros Brachiaria e Panicum em sistema plantio direto. Revista Ceres, v. 59, n. 2, p. 157-163, 2012.

GOMES JÚNIOR, F. G.; CHRISTOFFOLETI, P. J. Biologia e manejo de plantas daninhas em áreas de plantio direto. Planta Daninha, v. 26, n. 4, p. 789798, 2008.

LAMAS, F.M. Alternativas de cobertura do solo para a cultura do algodoeiro em Sistema Plantio Direto. Revista Plantio Direto, edição 103, janeiro/ fevereiro de 2008. Aldeia Norte Editora, Passo Fundo, RS. Disponível em: <http:// www.plantiodireto.com.br>. Acesso em: 01 jan. 2018.

LIMA, S. F. et al. Palhada de braquiária ruziziensis na supressão de plantas daninhas na cultura da soja. Revista Agrarian, v. 7, n. 26, p. 541-551, 2014.

LIMA, S. F.; TIMOSSI, P. C.; ALMEIDA, D. P. Métodos de semeadura e aplicação de 2,4-D na formação de braquiária ruziziensis para plantio direto. Cultura Agronômica, v. 25, n. 2, p. 175-186, 2016.

MORAES, C. P. DE. Controle e hormesis de glyphosate em Brachiaria decumbens. 2016. 62 f. Dissertação (Mestrado em Agronomia: Área de Concentração em Proteção de Plantas) Universidade Estadual Paulista "Júlio de Mesquita Filho", Botucatu, 2016.

NASCENTES, R. F. Hormesis de glyphosate em cana-de-açúcar e eucalipto. 2016. 63 f. Dissertação (Mestrado em Agronomia: Área de Concentração em Proteção de Plantas) - Universidade Estadual Paulista "Júlio de Mesquita Filho", Botucatu, 2016.

PARIZ, C. M. et al. Produtividade de grãos de milho e massa seca de braquiárias em consórcio no sistema de integração lavoura-pecuária. Ciência Rural, v. 41, n. 5 , p. $875-882,2011$.

QUEIROZ, R. F. et al. Maize intercropped with Urochloa ruziziensis under no-tillage system. Pesquisa Agropecuária Tropical, v. 46, n. 3, p. 238 -244, 2016.

REZENDE, P. N. et al. Eficiência de herbicidas aplicados em pós-emergência em milho consorciado com Urochloa brizantha cv. Marandu. Revista Agroambiente, v. 8, n. 3, p. 345-351, 2014.
RIBEIRO JÚNIOR, J. I. Análises estatísticas no SAEG. Viçosa, MG: UFV, 2001. 301p.

RODRIGUES, R. C. et al. Reservas orgânicas, relação parte aérea-raiz e $\mathrm{C}-\mathrm{N}$ e eliminação do meristema apical no capim-xaraés sob doses de nitrogênio e potássio. Ciência Animal Brasileira, v. 8, n. 3, p. 505-514, 2007.

RODRIGUES, R. C. et al. Produção de massa seca, relação folha/colmo e alguns índices de crescimento do Brachiaria brizantha cv. Xaraés cultivado com a combinação de doses de nitrogênio e potássio. Revista Brasileira de Zootecnia, v. 37, n. 3, p. 394 400, 2008.

RODRIGUES, B. N.; ALMEIDA, F. S. de. Guia de herbicidas. 6. ed. Londrina, PR: IAPAR, 2011. 764 p.

SBRISSIA, A. F.; DA SILVA, S. C. O ecossistema de pastagens e a produção animal. In: REUNIÃO ANUAL DA SOCIEDADE BRASILEIRA DE ZOOTECNIA, 38., 2001, Piracicaba. Anais... Piracicaba: SBZ, 2001. p. 731-754.

SILVA, U. R. da et al. Eficácia do glyphosate na dessecação de espécies de Urochloa. Revista Brasileira de Herbicidas, v. 12, n. 2, p. 202-209, 2013.

VELINI, E. D.; OSIPE, R.; GAZZIERO, D. L. P. Procedimentos para instalação, avaliação e análise de experimentos com herbicidas. Londrina, PR: SBCPD, 1995. 42 p.

ULBRICH, A. V.; SOUZA, J. R. P.; SHANER, D. Persistence and carryover effect of imazapic and imazapyr in Brazilian cropping systems. Weed Technology, v. 9, n. 4, p. 986-991, 2005. 